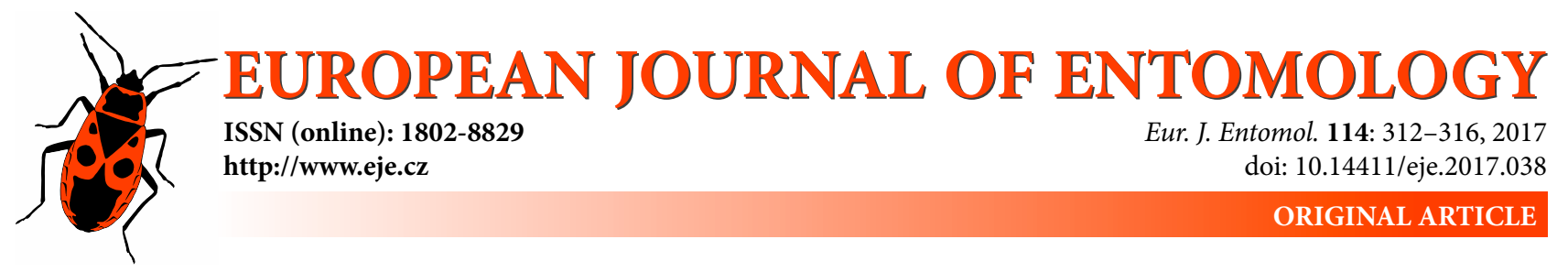

\title{
Metagenomic survey of bacteria associated with the invasive ladybird Harmonia axyridis (Coleoptera: Coccinellidae)
}

\author{
KRZYSzTof DUDEK ${ }^{1}$, KINGA HUMIŃSKA ${ }^{2,3}$, JACEK WOJCIECHOWICZ ${ }^{2}$ and PIOTR TRYJANOWSKI ${ }^{1}$ \\ ${ }^{1}$ Department of Zoology, Institute of Zoology, Poznań University of Life Sciences, Wojska Polskiego 71 C, 60-625 Poznań, \\ Poland; e-mails: dudeekk@gmail.com, piotr.tryjanowski@gmail.com \\ 2 DNA Research Center, Rubież 46, 61-612 Poznań, Poland; e-mails: k.huminska@cbdna.pl, j.wojciechowicz@cbdna.pl \\ ${ }^{3}$ Laboratory of High Throughput Technologies, Institute of Molecular Biology and Biotechnology, Faculty of Biology, \\ University of Adam Mickiewicz, Umultowska 89, 61-614 Poznan, Poland
}

Key words. Coleoptera, Coccinellidae, Harmonia axyridis, microbiota, bacteria community, 16s RNA, insect symbionts

\begin{abstract}
The Asian ladybird Harmonia axyridis is an invasive insect in Europe and the Americas and is a great threat to the environment in invaded areas. The situation is exacerbated by the fact that non native species are resistant to many groups of parasites that attack native insects. However, very little is known about the complex microbial community associated with this insect. This study based on sequencing 16S rRNA genes in extracted metagenomic DNA is the first research on the bacterial flora associated with $H$. axyridis. Lady beetles were collected during hibernation from wind turbines in Poland. A mean \pm SD of $114 \pm$ 35 species of bacteria were identified. The dominant phyla of bacteria recorded associated with $\mathrm{H}$. axyridis were Actinobacteria, Proteobacteria, Firmicutes and Bacteroidetes. Representatives of these phyla are common in the environment, e.g. in the soil, and are often identified as the dominant bacteria associated with arthropods. We also identified animal pathogenic bacteria, such as Burkholderia, Rhodococcus, Chlamydiae and Anaplasmataceae spp. (Neorickettsia helminthoeca and Ehrlichia ovina). We also identified Wolbachia pipientis in a single beetle. This bacterium is a causative agent of reproductive alterations in arthropods. These results support the enemy release hypothesis in the case of this ladybird invasion. Pathogenic bacteria were recorded in only a few samples. Moreover, male-killing bacteria such as Spiroplasma spp., Wolbachia spp. and Rickettsia spp. were only recorded in single insects so they cannot be responsible for the observed alterations in the sex-ratio of the ladybird population studied.
\end{abstract}

\section{INTRODUCTION}

Harmonia axyridis is an important invasive insect (Brown et al., 2008). This ladybird was intentionally introduced into Europe because it is an effective aphid predator (Koch, 2003). However, following its introduction, it has spread rapidly and has adversely affected native coccinellids and other organisms (Tedders \& Schaefer, 1994; Koch, 2003; Pervez \& Omkar, 2006; Pell et al., 2008; Brown et al., 2011). In Poland, this species was found for the first time in 2007 (Przewoźny et al., 2007) and it is now common throughout this country (Kubisz, 2014). H. axyridis hibernates frequently in anthropogenic structures e.g. houses, wind turbines (Labrie et al., 2008; Raak-Van den Berg et al., 2012; Dudek et al., 2015) in which its overwintering survival is high. It is possible that the invasive success of $H$. axyridis was enhanced by low parasitism, by which according to the enemy release hypothesis (Roy et al., 2011) an alien species leaves behind its enemies and pathogens in its original territory. Many studies has shown that invaders are less parasitized and attacked by predators than in their natural range (Torchin et al., 2002).

A large number of species of bacteria are known to be endosymbionts or entomopathogens of arthropods (Wernegreen, 2002; Boucias \& Pendland, 2012). However, there is very little information on the microbial community associated with insects. One reason is that there are very few bacteria that can be cultured, e.g. no more than $14 \%$ of all microorganisms in the sponge Haliclona sp. (Sipkema et al., 2011). Thus, traditional microbiological methods cannot identify a wide range of bacteria. Fortunately, recent techniques based on sequencing of 16S rRNA genes extracted from metagenomic DNA can provide a large amount of data on almost all of the microorganisms present in samples. This innovative technique is used to identify the diversity and species community in complex ecosystems (Venter et al., 2004; Sogin et al., 2006) or organisms (Carpi et al., 2011; Kaluzhnaya et al., 2012; Brooks et al., 2016) including humans (Dethlefsen et al., 2008; Victoria 
et al., 2009). Data on bacteria in ladybirds are scarce (Roy et al., 2011). All previous studies were only on a fragment of the bacterial metagenome and focused on specific organisms, especially male-killing bacteria, e.g. Spiroplasma spp. (Hurst et al., 1999a; Majerus et al., 1999; Nakamura et al., 2005), Rickettsia spp. (Werren et al., 1994) and Wolbachia spp. (Hurst et al., 1999b). To the best of our knowledge there has, to date, been no studies on the bacterial community of ladybirds.

The main goal of the present study was to describe the metagenomics of the bacterial community associated with $H$. axyridis in its invaded area. This survey might answer some important questions about pathogen occurrence in ladybirds, e.g. the male-killing bacteria that affect the sex ratios of insects. Moreover, we tested two different DNA isolation kits in order to assess their usefulness for isolating bacterial DNA from insects.

\section{MATERIAL AND METHODS}

\section{Material collection}

The ladybirds used in this study were collected from a wind farm located west of Gołańcz in the Wielkopolska region of Poland $\left(52^{\circ} 57^{\prime} \mathrm{N}, 17^{\circ} 14^{\prime} \mathrm{E}\right)$. The wind farm is in an intensive agricultural landscape dominated by oilseed rape and wheat crops. Insects were collected during October and November 2015 from 16 wind turbines (for area description see Dudek et al., 2015).

\section{DNA isolation}

DNA from ladybirds was isolated by mechanical lysis (bead beating) using a FastPrep24 instrument and deposits A (MPBiomedicals, CA, USA). Lysis was carried out at a speed of 6.5 $\mathrm{m} / \mathrm{s}$ for $40 \mathrm{~s}$ in 2 cycles (samples were cooled on ice for $5 \mathrm{~min}$ between cycles). Further steps in the isolation were performed using a NucleoSpin Tissue Kit (MACHEREY-NAGEL, Germany) and DNA Mini Kit (Qiagen, Hilden, Germany) according to the manufacturers protocols. Samples $1-10$ were isolated using the NucleoSpin Tissue kit (Kit I) and 11-15 using the DNA Mini Kit (Kit II). The concentration and purity of isolated DNA were measured spectrophotometrically at wavelengths of A260 and A280 using NanoDrop (ThermoScientific, DE, USA).

\section{Library preparation and sequencing}

The composition of ladybird microbiota was determined using 16S rRNA gene amplicon MiSeq-based high throughput sequencing (Illumina, CA, USA). Sequences of primers targeting V3V4 hypervariable region of 16S rRNA were as follows: 16S F: 5'-CCTACGGGNGGCWGCAG-3' and 16S_R: 5'-GACTACHVGGGTATCTAATCC-3'. These primers also contained the overhang adapter sequences attached to the 5 ' end of primers, compatible with the MiSeq flow cell adapters (Illumina, CA, USA).

Amplification of hypervariable regions (V3 and V4) of 16S rRNA was performed to characterize the taxonomic diversity present in samples of ladybirds. PCR reaction containing $2.5 \mu \mathrm{l}$ of genomic DNA $(\sim 5 \mathrm{ng} / \mu \mathrm{l}), 5 \mu \mathrm{l}$ of each primer $(1 \mu \mathrm{M})$ and 12.5 $\mu 1$ of $2 \times$ KAPA HiFi HotStart ReadyMix kit (KAPA BIOSYSTEMS, USA) was run on a ProFlex PCR System thermal cycler (Applied Biosystem, MA, USA).

Cycling conditions were as follows: initial denaturation at $95^{\circ} \mathrm{C}$ for $3 \mathrm{~min} ; 25$ cycles: denaturation at $95^{\circ} \mathrm{C}$ for $30 \mathrm{~s}$, annealing at $55^{\circ} \mathrm{C}$ for $30 \mathrm{~s}$, extension at $72^{\circ} \mathrm{C}$ for $30 \mathrm{~s}$ and final extension at $72^{\circ} \mathrm{C}$ for $5 \mathrm{~min}$.

The second amplification was performed using the PCR product from the first reaction as a template in order to index the samples for multiplexing. This reaction contained $5 \mu \mathrm{l}$ of product from the first PCR reaction, $5 \mu$ of P5 and P7 indices (Nextera Index v2 Kit, Illumina), $25 \mu 1$ of $2 \times$ KAPA HiFi HotStart ReadyMix kit (KAPA BIOSYSTEMS, USA) and $10 \mu \mathrm{l}$ of nuclease-free water. Cycling conditions were similar to the first PCR amplification but with the number of cycles reduced to 8 .

After each PCR reaction the amplified fragments with tags and adapters were purified using AMPure XP beads (Beckman Coulter Genomic, CA, USA). Amplicon concentrations were quantified using a Qubit fluorometer (Invitrogen, Carlsbad, CA, USA), normalized to $4 \mathrm{nM}$ and pooled prior to sequencing. To control the purity of DNA libraries, sterile water was used.

The $10 \mathrm{pM}$ library containing 15 pooled indexed samples with $26 \%$ spike-in PhiX control DNA was loaded onto the MiSeq sequencing platform. $2 \times 300$ pair end sequencing was performed using the MiSeq Reagent Kit $\times 3$ (600 cycles).

MiSeq Reporter software was used for the secondary data analysis. An average number of 18,800 reads (pass filter) per sample was obtained. Microbiome classification was performed based on the Greengenes database (http://greengenes.lbl.gov/).

\section{Statistical analyses}

Statistical analyses were done using SPSS v.21 software.

\section{RESULTS}

A total of 293,010 pairs of reads were generated for the ladybird microbiome of which 282,402 (96.4\%) passed quality filtering. The mean number of reads per sample was 19,534 (minimum 1,743 and maximum 63,926). There was a significant influence of the method of isolating DNA on the number of the reads (Mann-Whitney $U$ test $Z=-3.062$; $\mathrm{p}<0.001)$ but not on the quality ( $>0.05$ ). In the ladybirds studied a mean \pm SD of $114 \pm 35$ species of bacteria were identified. The number of pathogens identified strongly depended on the method used to isolate DNA. A mean of $145 \pm 50$ species of bacteria were identified using kit I and only $50 \pm 5$ when kit II was used (Mann-Whitney U test $\mathrm{Z}=-2.819 ; \mathrm{p}=0.003$; Table 1 ). The most common phyla identified in ladybirds were: Actinobacteria (identified in 15 beetles), Proteobacteria (15), Firmicutes (15), Bacteroidetes (14), Thermotogae (9) and Cyanobacteria (8). Only two species were identified in all the insects sampled: Rhodococcus baikonurensis and R. qingshengii. Aminobacter aminovorans was also dominant and identified in 11 samples. All bacterial DNA identified (from the top seven reads per sample) is presented in Table 2 .

Table 1. Number of bacteria identified at each taxonomic level using two different methods of isolating DNA.

\begin{tabular}{lccccc}
\hline DNA isolation Kit I & $\mathrm{N}$ & Min & Max & Mean & SEM \\
\hline Species & 10 & 59 & 587 & 145 & 49.84 \\
Genus & 10 & 63 & 134 & 92 & 7.58 \\
Family & 10 & 44 & 82 & 60 & 4.16 \\
Order & 10 & 22 & 38 & 28 & 1.63 \\
Class & 10 & 11 & 20 & 15 & 0.94 \\
Phylum & 10 & 6 & 12 & 9 & 0.63 \\
\hline DNA isolation Kit II & $\mathrm{N}$ & Min & Max & Mean & SEM \\
\hline Species & 5 & 35 & 65 & 50 & 5.21 \\
Genus & 5 & 29 & 54 & 42 & 4.23 \\
Family & 5 & 23 & 40 & 30 & 2.96 \\
Order & 5 & 12 & 23 & 15 & 2.03 \\
Class & 5 & 7 & 13 & 10 & 1.02 \\
Phylum & 5 & 4 & 9 & 6 & 0.86 \\
\hline
\end{tabular}


Table 2. Bacteria identified associated with the bodies of ladybirds. For each individual the top seven reads were assigned to a taxonomic status. $\#-$ number of ladybird samples where a taxon was identified $(15=100 \%)$.

\begin{tabular}{|c|c|c|c|c|c|c|c|c|c|c|c|}
\hline \multirow{18}{*}{$\begin{array}{c}\text { Phylum } \\
\text { Actinobacteria } \\
\end{array}$} & \# & Class & \# & Order & $\#$ & Family & \# & Genus & \# & Species & \# \\
\hline & 15 & Actinobacteria & 15 & Actinomycetales & 15 & Nocardiaceae & 15 & Rhodococcus & 15 & Rhodococcus baikonurensis & 15 \\
\hline & & & & & & & & & & Rhodococcus percolatus & 1 \\
\hline & & & & & & & & & & Rhodococcus qingshengii & 15 \\
\hline & & & & & & Microbacteriaceae & 9 & Cryocola & 6 & Cryocola antiquus & 1 \\
\hline & & & & & & & & Agrococcus & 1 & Agrococcus terreus & 1 \\
\hline & & & & & & & & Microbacterium & 1 & Microbacterium marinilacus & 1 \\
\hline & & & & & & & & Agromyces & 1 & Agromyces ramosus & 1 \\
\hline & & & & & & & & Mycetocola & 1 & & \\
\hline & & & & & & & & Leucobacter & & Leucobacter komagatae & 1 \\
\hline & & & & & & Streptomycetaceae & 3 & & & & \\
\hline & & & & & & Corynebacteriaceae & 2 & Corynebacterium & 1 & Corynebacterium coyleae & 1 \\
\hline & & & & & & Actinosynnemataceae & 1 & & & & \\
\hline & & & & & & Actinomycetaceae & & Rothia & 1 & Rothia mucilaginosa & 1 \\
\hline & & & & & & Intrasporangiaceae & 1 & Janibacter & 1 & Janibacter anophelis & 1 \\
\hline & & & & & & Micrococcaceae & 1 & & & & \\
\hline & & & & & & Pseudonocardiaceae & & Saccharopolyspora & 1 & $\begin{array}{l}\text { Saccharopolyspora } \\
\text { shandonaensis }\end{array}$ & 1 \\
\hline & & & & Kineosporiales & & Kineosporiaceae & 1 & Kineococcus & 1 & & \\
\hline \multirow{24}{*}{ Proteobacteria } & 15 & Alphaproteobacteria & 15 & Rhizobiales & 15 & Phyllobacteriaceae & 12 & Mesorhizobium & 5 & Mesorhizobium septentrionale & 3 \\
\hline & & & & & & & & Aminobacter & 11 & Aminobacter aganoensis & 1 \\
\hline & & & & & & & & & & Aminobacter aminovorans & 11 \\
\hline & & & & & & & & Pseudaminobacter & & Pseudaminobacter defluvii & 1 \\
\hline & & & & & & Rhizobiaceae & 6 & Agrobacterium & 4 & Agrobacterium tumefaciens & 3 \\
\hline & & & & & & & & Rhizobium & 1 & & \\
\hline & & & & & & Hyphomicrobiaceae & & Devosia & 1 & Devosia limi & 1 \\
\hline & & & & & & Brucellaceae & 2 & Ochrobactrum & 2 & Ochrobactrum thiophenivorans & 4 \\
\hline & & & & & & Methylobacteriaceae & 1 & & & & \\
\hline & & & & Sphingomonadales & 8 & Sphingomonadaceae & 4 & Sphingomonas & 4 & Sphingomonas leidyia & 2 \\
\hline & & & & & & & & & & Sphingomonas oligophenolica & 1 \\
\hline & & & & Rickettsiales & 4 & Rickettsiaceae & 1 & Wolbachia & 1 & Wolbachia pipientis & 1 \\
\hline & & & & & & Anaplasmataceae & 1 & Neorickettsia & 1 & Neorickettsia helminthoeca & 1 \\
\hline & & & & & & & & Ehrlichia & 1 & Ehrlichia ovina & 1 \\
\hline & & & & Rhodospirillales & 1 & Acetobacteraceae & 1 & Roseomonas & 1 & Roseomonas terpenica & 1 \\
\hline & & Betaproteobacteria & 15 & Burkholderiales & 15 & Comamonadaceae & 15 & Delftia & 9 & Delftia lacustris & $\frac{1}{5}$ \\
\hline & & & & & & & & & & Delftia tsuruhatensis & 6 \\
\hline & & & & & & & & Polaromonas & 8 & $\begin{array}{c}\text { Polaromonas } \\
\text { Panthalenivorans }\end{array}$ & 1 \\
\hline & & & & & & Burkholderiaceae & 1 & Burkholderia & 1 & $\begin{array}{l}\text { napninalenivorans } \\
\text { Burkholderia sordidicola }\end{array}$ & 1 \\
\hline & & Gammaproteobacteria & 14 & Xanthomonadales & 13 & Xanthomonadaceae & 10 & Stenotrophomonas & 9 & Stenotrophomonas maltophilia & 1 \\
\hline & & & & & & & & & & Stenotrophomonas pavanii & 1 \\
\hline & & & & & & & & Luteimonas & 1 & & \\
\hline & & & & Pseudomonadales & 2 & Moraxellaceae & & Enhydrobacter & & Enhydrobacter aerosaccus & 1 \\
\hline & & & & Enterobacteriales & 1 & Enterobacteriaceae & 1 & & & & \\
\hline \multirow[t]{12}{*}{ Firmicutes } & 15 & Bacilli & 14 & Bacillales & 8 & Bacillaceae & 3 & Bacillus & 2 & Bacillus Iongiquaesitum & 1 \\
\hline & & & & & & & & & & Bacillus pseudofirmus & 1 \\
\hline & & & & & & Sporolactobacillaceae & 1 & Pullulanibacillus & 1 & Pullulanibacillus naganoensis & 1 \\
\hline & & & & & & Paenibacillaceae & 1 & Brevibacillus & 1 & Brevibacillus ginsengisoli & 1 \\
\hline & & & & Lactobacillales & 7 & Carnobacteriaceae & 2 & Carnobacterium & 2 & & \\
\hline & & & & & & Streptococcaceae & 2 & Lactococcus & 2 & Lactococcus fujiensis & 1 \\
\hline & & & & & & & & & & Lactococcus lactis & 2 \\
\hline & & & & Turicibacterales & 1 & & & & & & \\
\hline & & Clostridia & 11 & Clostridiales & 9 & Clostridiaceae & 4 & Alkaliphilus & 2 & Alkaliphilus peptidifermentans & 2 \\
\hline & & & & & & & & Clostridium & 1 & Clostridium cadaveris & 2 \\
\hline & & & & & & Lachnospiraceae & & Johnsonella & & Johnsonella ignava & 1 \\
\hline & & Mollicutes & 1 & Acholeplasmatales & 1 & Acholeplasmataceae & & Phytoplasma & & Phytoplasma prunorum & 1 \\
\hline Bacteroidetes & 14 & Flavobacteriia & 2 & Flavobacteriales & 1 & Flavobacteriaceae & 1 & Chryseobacterium & 1 & Chryseobacterium caeni & 1 \\
\hline Thermotogae & 9 & & & & & & & & & & \\
\hline \multirow[t]{3}{*}{ Cyanobacteria } & 8 & Nostocophycideae & 2 & Stigonematales & 2 & & & & & & \\
\hline & & & & Nostocales & 1 & Rivulariaceae & 2 & Calothrix & 2 & Calothrix parietina & 3 \\
\hline & & Synechococcophycideae & 1 & Pseudanabaenales & 1 & Pseudanabaenaceae & 1 & Leptolyngbya & 1 & Leptolyngbya laminosa & 1 \\
\hline Tenericutes & 4 & & & & & & & & & & \\
\hline Verrucomicrobia & 3 & & & & & & & & & & \\
\hline Thermi & 2 & & & & & & & & & & \\
\hline Nitrospirae & 1 & & & & & & & & & & \\
\hline Acidobacteria & 1 & & & & & & & & & & \\
\hline Chlamydiae & 1 & & & & & & & & & & \\
\hline Chloroflexi & 1 & & & & & & & & & & \\
\hline Fusobacteria & 1 & & & & & & & & & & \\
\hline anctomycetes & & & & & & & & & & & \\
\hline
\end{tabular}

\section{DISCUSSION}

Sample size was limited by the high cost of this very modern and expensive method; hence the results should be treated with caution. However, because of the novelty of the findings they merit a broad discussion. The dominant phyla of bacteria in the $H$. axyridis analyzed were Acti- nobacteria, Proteobacteria, Firmicutes and Bacteroidetes. These microorganisms were present in all the insects sampled regardless of the method of isolation used (except for Bacteroidetes, which were not present in one sample). Representatives of these phyla are common in the environment, e.g. in the soil, and are often identified as dominant 
bacteria associated with arthropods (Carpi et al., 2011; Kaluzhnaya et al., 2012). Thermotogae and Cyanobacteria were also detected in the majority of the samples ( 9 and 8 respectively). Cyanobacteria are autotrophic organisms existing in almost all environments and often detected associated with other organisms (Whitton, 2012). The detection of Thermotogae bacteria associated with hibernating ladybirds was surprising. These Gram-negative bacteria are extremely thermophilic and occur mostly in thermal springs (Bhandari \& Gupta, 2014). Unfortunately, these analyses did not recognize any lower taxonomic level for this phylum. In four ladybirds Tenericutes bacteria were found, to which Spiroplasma spp. belongs; which are common bacteria in the gut and haemolymph of insects and known as male-killing bacteria (Hurst et al., 1999a; Majerus et al., 1999; Nakamura et al., 2005). Interestingly, in one insect, bacteria belonging to the Chlamydiae were detected, which are obligate intracellular pathogens mostly known as the causative agent of sexually transmitted diseases in humans, but also associated with insects (Thao et al., 2003).

We also identified animal pathogenic bacteria, such as Burkholderia, Rhodococcus and Anaplasmataceae spp., such as Neorickettsia helminthoeca and Ehrlichia ovina, which are often transmitted by ticks (Ekner et al., 2011; Matysiak et al., 2016). Another group of mostly endosymbiotic or pathogenic bacteria is the Rickettsiales, which we recorded in four samples. These microorganisms are common in arthropods (Weinert et al., 2009), so it is curious that were recorded them in only a few of the samples of ladybirds studied. The Wolbachia genus also belongs to this family and we identified $W$. pipientis in a single beetle. This bacterium is the causative agent of reproductive alterations in arthropods (Stouthamer et al., 1999). R. qingshengii is a carbendazim-degrading bacterium recorded in contaminated soil in China (Xu et al., 2007). However, it is also a pathogen of Atlantic salmon (Avendano-Herrera et al., 2011) and recorded in an alpine glacier at a site subject to high levels of human activity (Lee et al., 2011) so this bacterium might be associated with ladybeetles collected from polluted soil around wind turbines. The second species of this genus recorded in all samples was R. baikonurensis, which is a soil bacterium (Yoon et al., 2010) and was isolated for the first time in the air in the Mir space station (Li et al., 2004). R. baikonurensis is known to degrade oil (Lee et al., 2006) and its presence on ladybeetles, like that of $R$. qingshengii, might be linked with the polluted environment around wind turbines.

This study is the first metagenomic research on the bacterial flora associated with the invasive ladybird $H$. axyrid$i s$. Results indicate that the bacterial community associated with $H$. axyridis consists mostly of symbiotic organisms, widely distributed in the environment. The results also support the enemy release hypothesis applying in the case of this ladybird invasion. Pathogenic bacteria were found in only a few samples. Moreover, male-killing bacteria, such as Spiroplasma spp., Wolbachia spp. and Rickettsia spp., were only found in single insects so they cannot be responsible for the observed alterations in the sex-ratio of the ladybird population studied (the sex-ratio was strongly skewed towards females $-65.9 \%$ female, chi-square with Yates correction $\chi^{2}=60.813, \mathrm{p}<0.0001-$ unpubl. data). The comparison of the two kits for DNA isolation revealed significant differences (a mean of 145 vs. 50 species of bacteria were detected). The NucleoSpin Tissue Kit isolated much more material than the DNA Mini Kit, which might be a consequence of the greater purity of the DNA extracted by the first kit (Queipo-Ortuno et al., 2008). Thus based on this comparison it is recommended that the $\mathrm{Nu}-$ cleoSpin Tissue Kit be used in future research.

ACKNOWLEDGEMENTS. This work was supported by the Genomic Laboratory, DNA Research Centre, Poznan, Poland, which financed and carried out material homogenization, DNA isolation, library preparation and NGS sequencing. We thank M. Grzanka for help with the wet-laboratory work. Field work was supported by the grant no. 507.511.55 from Poznan University of Life Sciences. We thank professor T. Sparks for editing the English. The authors have no conflict of interest to declare.

\section{REFERENCES}

Avendano-Herrera R., Balboa S., Doce A., Ilardi P., Lovera P., Toranzo A.E. \& Romalde J.L. 2011: Pseudo-membranes on internal organs associated with Rhodococcus qingshengii infection in Atlantic salmon (Salmo salar). — Vet. Microbiol. 147: 200-204.

Bhandari V. \& Gupta R.S. 2014: The Phylum Thermotogae. In Rosenberg E., DeLong E.F., Lory S., Stackebrandt E. \& Thompson F. (eds): The Prokaryotes. Vol. 11. 4. ed. Springer, Berlin, Heidelberg, pp. 989-1015.

Boucias D. \& Pendland J.C. 2012: Principles of Insect Pathology. Springer Science \& Business Media, new York, 550 pp.

Brooks A.W., Kohl K.D., Brucker R.M., van Opstal E.J. \& BorDENSTEIN S.R. 2016: Phylosymbiosis: Relationships and functional effects of microbial communities across host evolutionary history. — PLoS Biol. 14(11): e2000225, 29 pp.

Brown P., Adriaens T., Bathon H., Cuppen J., Goldarazena A., Hägg T., Kenis M., Klausnitzer B., KovÁř I. \& Loomans A. 2008: Harmonia axyridis in Europe: spread and distribution of a non-native coccinellid. - BioControl 53: 5-21.

Brown P.M., Frost R., Doberski J., Sparks T., Harrington R. \& Roy H.E. 2011: Decline in native ladybirds in response to the arrival of Harmonia axyridis: early evidence from England. Ecol. Entomol. 36: 231-240.

Carpi G., Cagnacci F., Wittekindt N.E., Zhao F., Qi J., Tomsho L.P., Drautz D.I., Rizzoli A. \& Schuster S.C. 2011: Metagenomic profile of the bacterial communities associated with Ixodes ricinus ticks. - PLoS ONE 6(10): e25604, 11 pp.

Dethlefsen L., Huse S., Sogin M.L. \& Relman D.A. 2008: The pervasive effects of an antibiotic on the human gut microbiota, as revealed by deep $16 \mathrm{~S}$ rRNA sequencing. - PLoS Biol. 6(11): e280, 18 pp.

Dudek K., Dudek M. \& Tryjanowski P. 2015: Wind turbines as overwintering sites attractive to an invasive lady beetle, Harmonia axyridis Pallas (Coleoptera: Coccinellidae). - Coleopt. Bull. 69: 665-669.

Ekner A., Dudek K., Sajkowska Z., Majláthová V., Majláth I. \& Tryjanowski P. 2011: Anaplasmataceae and Borrelia burgdorferi sensu lato in the sand lizard Lacerta agilis and co-infection of these bacteria in hosted Ixodes ricinus ticks. - Parasit. Vectors 4: 182, 7 pp. 
Hurst G., Schulenburg J., Majerus T., Bertrand D., Zakharov I., Baungaard J., Völkl W., Stouthamer R. \& Majerus M. 1999a: Invasion of one insect species, Adalia bipunctata, by two different male-killing bacteria. - Insect Mol. Biol. 8: $133-139$

Hurst G.D., Jiggins F.M., von der Schulenburg J.H.G., Bertrand D., West S.A., Goriacheva I.I., Zakharov I.A., WerReN J.H., Stouthamer R. \& Majerus M.E. 1999b: Male-killing Wolbachia in two species of insect. - Proc. R. Soc. Lond. (B) 266: 735-740.

Kaluzhnaya O., Krivich A. \& Itskovich V. 2012: Diversity of 16S rRNA genes in metagenomic community of the freshwater sponge Lubomirskia baicalensis. - Russ. J. Genet. 48: $855-858$

KocH R.L. 2003: The multicolored Asian lady beetle, Harmonia axyridis: A review of its biology, uses in biological control, and non-target impacts. - J. Insect Sci. 3: 32, 16 pp.

KuBISZ D. 2014: Harmonia axyridis (Pallas, 1773). In Głowaciński Z., Okarma H., Pawłowski J. \& Solarz W. (eds): Gatunki obce $w$ faunie Polski. [Alien Species in Polish Fauna.] URL: http://www.iop.krakow.pl/gatunkiobce/default8923.html? nazwa $=$ opis\&id $=120 \& j e=p l$ (last accessed 12 Jun. 2017).

LABrie G., Coderre D. \& LuCAS E. 2008: Overwintering strategy of multicolored Asian lady beetle (Coleoptera: Coccinellidae) cold-free space as a factor of invasive success. - Ann. Entomol. Soc. Am. 101: 860-866.

Lee M., Kim M., Singleton I., Goodfellow M. \& Lee S.T. 2006: Enhanced biodegradation of diesel oil by a newly identified Rhodococcus baikonurensis EN3 in the presence of mycolic acid. - J. Appl. Microbiol. 100: 325-333.

Lee Y.M., Kim S.-Y., Jung J., Kim E.H., Сho K.H., Schinner F., Margesin R., Hong S.G. \& Lee H.K. 2011: Cultured bacterial diversity and human impact on alpine glacier cryoconite. $-J$. Microbiol. 49: 355-362.

Li Y., Kawamura Y., Fujiwara N., NaKa T., Liu H., Huang X., KoBAYASHI K. \& EZAKI T. 2004: Rothia aeria sp. nov., Rhodococcus baikonurensis sp. nov. and Arthrobacter russicus sp. nov., isolated from air in the Russian space laboratory Mir. - Int. J. Syst. Evol. Microbiol. 54: 827-835.

Majerus T., Der Schulenburg V., Graf J., Majerus M. \& Hurst G. 1999: Molecular identification of a male-killing agent in the ladybird Harmonia axyridis (Pallas) (Coleoptera: Coccinellidae). - Insect Mol. Biol. 8: 551-555.

Matysiak A., Dudko P., Dudek K., Dudek M., Junkuszew A. \& TRYJANOWSKI P. 2016: The occurrence of pathogens in Rhipicephalus microplus ticks from cattle in Madagascar. - Vet. Med. (Praha) 61: 516-523.

NaKamura K., Ueno H. \& Miura K. 2005: Prevalence of inherited male-killing microorganisms in Japanese population of ladybird beetle Harmonia axyridis (Coleoptera: Coccinellidae). - Ann. Entomol. Soc. Am. 98: 96-99.

Pell J.K., Baverstock J., Roy H.E., Ware R.L. \& Majerus M.E. 2008: Intraguild predation involving Harmonia axyridis: A review of current knowledge and future perspectives. - BioControl 53: $147-168$.

Pervez A. \& OmKar 2006: Ecology and biological control application of multicoloured Asian ladybird, Harmonia axyridis: A review. - Biocontr. Sci. Technol. 16: 111-128.

Przewoźny M., BarŁożeK T. \& Bunalski M. 2007: Harmonia axyridis (Pallas, 1773) (Coleoptera: Coccinellidae) new species of ladybird beetle for Polish fauna. - Pol. J. Entomol. 76: $177-182$.
Queipo-Ortuno M., Tena F., Colmenero J. \& Morata P. 2008: Comparison of seven commercial DNA extraction kits for the recovery of Brucella DNA from spiked human serum samples using real-time PCR. - Eur. J. Clin. Microbiol. Infect. Dis. 27: 109-114.

Raak-Van den Berg C., Hemerik L., de Jong P.W. \& van LenTEREN J.C. 2012: Mode of overwintering of invasive Harmonia axyridis in the Netherlands. - BioControl 57: 71-84.

Roy H.E., Rhule E., Harding S., Handley L.-J.L., Poland R.L., Riddick E.W. \& Steenberg T. 2011: Living with the enemy: parasites and pathogens of the ladybird Harmonia axyridis. BioControl 56: 663-679.

Sipkema D., Schippers K., Maalcke W.J., Yang Y., Salim S. \& BLANCH H.W. 2011: Multiple approaches to enhance the cultivability of bacteria associated with the marine sponge Haliclona (gellius) sp. - Appl. Environ. Microbiol. 77: 2130-2140.

Sogin M.L., Morrison H.G., Huber J.A., Welch D.M., Huse S.M., Neal P.R., Arrieta J.M. \& Herndl G.J. 2006: Microbial diversity in the deep sea and the underexplored "rare biosphere". - Proc. Nat. Acad. Sci. 103: 12115-12120.

Stouthamer R., Breeuwer J.A. \& Hurst G.D. 1999: Wolbachia pipientis: microbial manipulator of arthropod reproduction. Annu. Rev. Microbiol. 53: 71-102.

Tedders W. \& Schaefer P. 1994: Release and establishment of Harmonia axyridis (Coleoptera: Coccinellidae) in the southeastern United States. - Entomol. News 105: 228-243.

Thao M.L., Baumann L., Hess J.M., Falk B.W., Ng J.C., Gullan P.J. \& Baumann P. 2003: Phylogenetic evidence for two new insect-associated Chlamydia of the family Simkaniaceae. Curr. Microbiol. 47: 46-50.

TORChin M., LAFFERTY K. \& KURIS A. 2002: Parasites and marine invasions. - Parasitology 124: 137-151.

Venter J.C., Remington K., Heidelberg J.F., Halpern A.L., Rusch D., Eisen J.A., Wu D., Paulsen I., Nelson K.E. \& NelSON W. 2004: Environmental genome shotgun sequencing of the Sargasso Sea. - Science 304: 66-74.

Victoria J.G., Kapoor A., Li L., Blinkova O., Slikas B., Wang C., Naeem A., Zaidi S. \& Delwart E. 2009: Metagenomic analyses of viruses in stool samples from children with acute flaccid paralysis. - J. Virol. 83: 4642-4651.

Weinert L.A., Werren J.H., Aebi A., Stone G.N. \& Jiggins F.M. 2009: Evolution and diversity of Rickettsia bacteria. - BMC Biol. 7: 6, 15 pp.

WERNEGREEN J.J. 2002: Genome evolution in bacterial endosymbionts of insects. - Nature Rev. Genet. 3: 850-861.

Werren J.H., Hurst G., Zhang W., Breeuwer J., Stouthamer R. \& MaJERus M. 1994: Rickettsial relative associated with male killing in the ladybird beetle (Adalia bipunctata). - J. Bacteriol. 176: 388-394.

Whitton B.A. 2012: Ecology of Cyanobacteria II: Their Diversity in Space and Time. Springer Science \& Business Media, $760 \mathrm{pp}$.

Xu J.-L., He J., Wang Z.-C., Wang K., Li W.-J., Tang S.-K. \& LI S.-P. 2007: Rhodococcus qingshengii sp. nov., a carbendazim-degrading bacterium. - Int. J. Syst. Evol. Microbiol. 57: 2754-2757.

Yoon J., Miwa H., Ahmed I., Yokota A. \& Fujiwara T. 2010: Rhodococcus baikonurensis BTM4c, a boron-tolerant actinobacterial strain isolated from soil. - Biosci. Biotechnol. Biochem. 74: $178-181$.

Received April 25, 2017; revised and accepted May 18, 2017 Published online June 13, 2017 